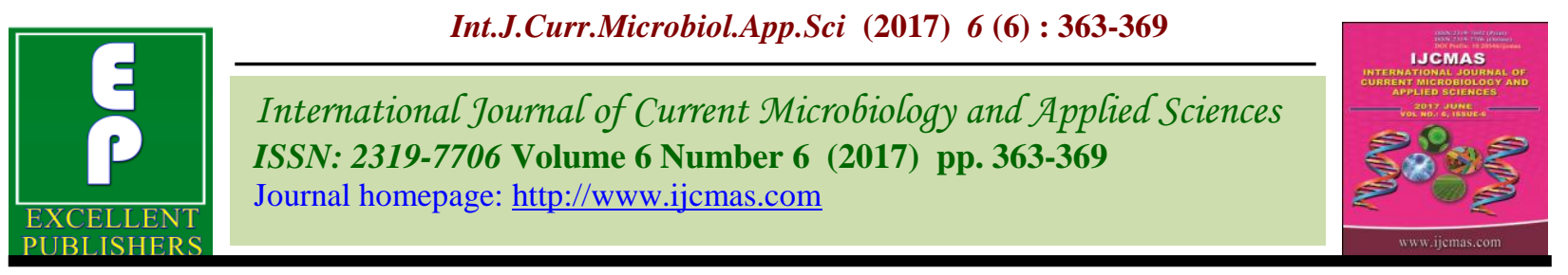

Original Research Article

https://doi.org/10.20546/ijcmas.2017.606.042

\title{
Study of Microbial Flora of Female Genital Tract in Intrauterine Contraceptive Device Users
}

\author{
K. Subha*, R. Selvi, A.V.M. Balaji, and D. Dheepa \\ Department of Microbiology, Government Thoothukudi Medical College, Thoothukudi-628008, \\ Tamilnadu, India \\ *Corresponding author
}

\section{A B S T R A C T}

An intrauterine device used by more than 150 millions of women worldwide is one of the most efficient methods of contraception. The aim of the study is to

\begin{tabular}{|l|}
\hline Ke y w o r d s \\
IUCD, \\
Bacterial \\
vaginosis, \\
Actinomyces \\
\hline Article Info \\
\hline Accepted: \\
04 May 2017 \\
Available Online: \\
10 June 2017 \\
\hline \hline
\end{tabular}
compare the genital tract microbial flora of women prior to and after insertion of IUCD and to find out the relation of microbial flora of removed IUCDs with duration of its use. The study included 40 women who came for IUCD insertion and 80 IUCD users who came for follow up and/or removal of IUCD. High vaginal swabs, endocervical swabs and IUCDs were collected and subjected to Gram staining. Aerobic, anaerobic and fungal culture were done and interpreted according to standard microbiological procedures and methods. Significant occurrence of bacterial vaginosis was observed in women with IUCD in situ. The isolation rate of Actinomyces species was significantly higher in women with IUCD in situ when compared to women prior to insertion. The isolation rate of Actinomyces and Candida increased with the duration of the device in utero. IUCD usage results in increased occurrence of bacterial vaginosis and increased isolation of Actinomyces species. Hence women using IUCD requires a regular follow up, further investigation and treatment as needed.

\section{Introduction}

The safety, effectiveness and acceptability of the currently available intrauterine contraceptive devices (IUCD) have ranked it to be the most popular reversible contraceptive method used by more than 150 millions of women worldwide. IUCD use is high $(14.5 \%)$ in developing countries and low (7.6\%) in developed countries (14). In India copper releasing IUCD is the second most commonly used family planning after voluntary female sterilization.
The microbial flora of female genital tract is a dynamic, complex example of microbial colonization and this equilibrium may be disturbed by physiologic or nonphysiologic changes. The use of IUCD, especially the tail of the device, may change the normal vaginal flora from aerobic to anaerobic which favours the growth of bacterial vaginosis associated bacteria. Several studies suggest that the tail of the device might facilitate the ascent of cervicovaginal microorganisms into the uterus (3, 11). Therefore, pathogenic 
microorganisms can be transferred into the uterine cavity by the tail of IUCD. The insertion of such a device may promote the colonization of anaerobic microorganisms both on the tail of IUCD and the mucosa of the uterus. After this inoculation, these microorganisms may carry out the development of pelvic inflammatory disease $(3,11)$.

Recent research is helping to lift a cloud that has hung over the IUCD for the past several years. Although evidence of direct association between IUCD use and its related infection is scarce, concerns about pelvic inflammatory disease related to IUCD use has limited their use throughout the world.

Hence the study was undertaken to compare the microbial flora of the female genital tract of women prior to, after insertion and at the time of removal of IUCD.

\section{Materials and Methods}

Ethical committee clearance and informed consent was obtained for the present study. The study was conducted at RSRM hospital and Stanley Medical College, Chennai, Tamilnadu.

Inclusion criteria: Women attending Family Planning OP for IUCD insertion, women with IUCD in situ with or without symptoms and signs of genital tract infection, IUCD users in whom IUCD removal was advised by Gynaecologist, IUCD users with desire to conceive and IUCD users not willing to have IUCD for other complaints like haemorrhage, pregnancy etc. Exclusion criteria: Women with heavy blood flow during menstrual period at the time of sample collection or antibiotic use during previous 15 days and diabetic patients.

A total of 40 women prior to insertion taken as controls and 80 women with IUCD in situ were studied. Three high vaginal and 3 endo cervical swabs were obtained from all female study subjects. IUCDs were collected from IUCD users who came for IUCD removal. The swabs were subjected to direct Gram staining, aerobic, anaerobic and fungal culture. The vaginal swab direct smears were analysed for bacterial vaginosis and hyphal elements. Aerobic culture was done by inoculating into Blood agar, Mac Conkey agar, incubated at $37^{\circ} \mathrm{C}$ for $24 \mathrm{hrs}$ and were identified by gram staining, culture, biochemical reactions and subjected to antimicrobial susceptibility pattern. Anaerobic culture was done with Robertson cooked meat broth, blood agar, neomycin blood agar, incubated at $37^{\circ} \mathrm{C}$ for $48 \mathrm{hrs}$ and aerobic tolerance was checked by inoculating into blood agar and incubating aerobically. Anaerobes were identified by gram staining, culture and sensitivity to special discs colistin $(10 \mu \mathrm{g})$, vancomycin $(5 \mu \mathrm{g})$ and kanamycin $(1$ $\mathrm{mg})$ and metronidazole $(5 \mu \mathrm{g})$. Fungal culture was done with Sabouraud dextrose agar and incubation at $25^{\circ} \mathrm{C}$ for 1 week. Candida species were differentiated by germ tube test, cornmeal agar and CHROM agar.

The IUCDs removed under strict aseptic precautions were placed in brain heart infusion broth, Robertson cooked meat broth and subjected to aerobic, anaerobic and fungal culture and identified by standard laboratory methods (15).

\section{Results and Discussion}

A total of 40 women prior to insertion of IUCD and 80 women with IUCD in situ were included in the study. High vaginal swabs, endocervical swabs and IUCD were collected and processed for aerobic, anaerobic and fungal culture. The results are as follows:

The copper intrauterine device is an extremely effective, safe, long lasting, rapidly reversible method of contraception which has 
gained popularity worldwide. The studies on the microbiological profile of IUCD users showed diversity of microbes.

Most of the women who came for IUCD insertion and follow up were in the reproductive age group of 21-30 years (Table $2)$. This correlates with the studies $(9,5,2)$ in which majority of IUCD users were in the age group of 21 to 30 years. About $32.5 \%$ of women had low level of education.

The chief complaints of women with IUCD in situ were vaginal discharge $(50.9 \%)$ followed by backache $(40 \%)$ and lower abdominal pain $(38.9 \%)$. This correlates with the studies $(1$, 8) in which majority of IUCD users presented with vaginal discharge. This could be due to the presence of IUCD as a foreign body causing reaction to the host and response of endometrial tissue to the device as stated by Beerthuizen. Nayer has stated that cervical erosion due to constant irritation by thread of IUCD tail may be responsible for vaginal discharge.

Bacterial vaginosis was significantly higher $(23.8 \%)$ in women with IUCD in situ when compared to $10 \%$ of women prior to insertion. $(\mathrm{p}<0.05)$ (Table 1) This correlates with the study by Sayeste Demirezen et al., (10) in which an association between copper IUCD and bacterial vaginosis has been detected. A total of 6 women in whom the Nugents score was 4 to 6 at the time of insertion turned out to be more than 6 during follow up.
Lactobacilli were isolated at a lesser frequency from women with IUCD in situ when compared to women prior to insertion. $(\mathrm{p}<0.05)$ (Table 4). This correlates with the study by Elhag et al., (5) in which lactobacilli was found in less frequency in IUCD users. Lack of dominance of lactobacilli would lead to decreased production of hydrogen peroxide and lactic acid and thus promoting unrestricted growth of other constituents of the flora.

The isolation rate of aerobic bacteria from women with IUCD in situ was not statistically significant when compared to women prior to insertion (Table 3). This correlates with the studies $(1,5)$ in which no significance was found in isolation rate of individual organisms in women with IUCD in situ. But in Samar Ghazal et al., (9) study, higher rate of aerobic bacterial infection was found in women with IUCD in situ.

In the present study, Actinomyces spp was isolated only from women with IUCD in situ and none from women prior to insertion (Table 4). This correlates with the study by Elhag et al., (5) in which Actinomyces was only isolated from IUCD users. Valicenti et al., (13) study has stated that IUCD has been shown to induce a mild inflammatory response in the endometrium, with focal necrosis which creates an environment favourable for Actinomyces and other anaerobic organisms.

Table.1 Nugents scoring of vaginal smears

\begin{tabular}{|c|c|c|c|c|}
\hline Nugents score & $\begin{array}{c}\text { Women prior to IUCD } \\
\text { insertion }(\mathbf{n = 4 0})\end{array}$ & $\mathbf{\%}$ & $\begin{array}{c}\text { Women with IUCD } \\
\text { in situ }(\mathbf{n = 8 0})\end{array}$ & \% \\
\hline $0-3$ & 24 & 60 & 30 & 37.5 \\
\hline $4-6$ & 12 & 30 & 31 & 38.7 \\
\hline $7-10^{*}$ & 4 & 10 & 19 & 23.8 \\
\hline
\end{tabular}

* Score of 7-10 indicates bacterial vaginosis

Bacterial vaginosis was found in $10 \%$ of women prior to insertion and $23.8 \%$ of women with IUCD in situ (p<0.05). 
Table.2 Demographic factors

\begin{tabular}{|c|c|c|c|c|}
\hline Age group (yrs) & $\begin{array}{c}\text { Women prior to IUCD } \\
\text { insertion (n=40) }\end{array}$ & $\begin{array}{c}\text { Women with IUCD } \\
\text { in situ (n=80) }\end{array}$ & \% \\
\hline$<20$ & 2 & 5 & 5 & 6.3 \\
\hline $21-30$ & 9 & 72.5 & 61 & 76.2 \\
\hline $31-40$ & 0 & 22.5 & 13 & 16.3 \\
\hline $41-50$ & 13 & 32.5 & 26 & 1.2 \\
\hline Education & 25 & 62.5 & 47 & 58.5 \\
\hline Primary & 2 & 5 & 7 & 8.7 \\
\hline Secondary & 25 & 0 & & \\
\hline College & 210 & & & \\
\hline
\end{tabular}

Most of the women were in the age group of 21 to 30 years. One woman of 44 years age came for removal of IUCD after 12 years.

Table.3 Aerobic bacterial isolates obtained from high vaginal and endocervical swabs

\begin{tabular}{|c|c|c|c|c|c|c|c|c|}
\hline \multirow[b]{2}{*}{ Aerobes } & \multicolumn{4}{|c|}{ High vaginal swab isolates } & \multicolumn{4}{|c|}{ Endocervical swab isolates } \\
\hline & $\begin{array}{c}\text { Women } \\
\text { prior to } \\
\text { IUCD } \\
\text { insertion } \\
(n=40)\end{array}$ & $\%$ & $\begin{array}{c}\text { Women } \\
\text { with } \\
\text { IUCD in } \\
\text { situ } \\
(\mathrm{n}=80)\end{array}$ & $\%$ & $\begin{array}{l}\text { Women } \\
\text { prior to } \\
\text { IUCD } \\
\text { insertion } \\
(n=40)\end{array}$ & $\%$ & $\begin{array}{c}\text { Women } \\
\text { with IUCD } \\
\text { in situ } \\
(\mathbf{n}=\mathbf{8 0})\end{array}$ & $\%$ \\
\hline \multicolumn{9}{|l|}{ Gram positive: } \\
\hline $\begin{array}{c}\text { Staphylococcus } \\
\text { aureus }\end{array}$ & 4 & 10 & 12 & 15 & 2 & 5 & 8 & 10 \\
\hline $\begin{array}{l}\text { Coagulase negative } \\
\text { Staphylococci }\end{array}$ & 6 & 15 & 13 & 16.3 & 1 & 2.5 & 8 & 10 \\
\hline Enterococci & 4 & 10 & 10 & 12.5 & 2 & 5 & 7 & 8.8 \\
\hline $\begin{array}{c}\text { Beta hemolytic } \\
\text { Streptococci }\end{array}$ & 1 & 2.5 & 3 & 3.8 & 0 & 0 & 0 & 0 \\
\hline Diphtheroids & 5 & 12.5 & 9 & 11.3 & 2 & 5 & 3 & 3.8 \\
\hline \multicolumn{9}{|l|}{ Gram negative: } \\
\hline Escherichia coli & 4 & 10 & 12 & 15 & 3 & 7.5 & 8 & 10 \\
\hline Klebsiella & 2 & 5 & 6 & 7.5 & 1 & 2.5 & 4 & 5 \\
\hline Proteus & 1 & 2.5 & 2 & 2.5 & 0 & 0 & 2 & 2.5 \\
\hline Pseudomonas & 1 & 2.5 & 3 & 3.8 & 1 & 2.5 & 2 & 2.5 \\
\hline $\begin{array}{c}\text { Gardnerella } \\
\text { vaginalis }\end{array}$ & 4 & 10 & 20 & 25 & 1 & 2.5 & 3 & 3.8 \\
\hline
\end{tabular}

The isolation rate of aerobic bacteria from women with IUCD in situ was not statistically significant when compared to women prior to insertion. 
Table.4 Anaerobic bacterial isolates obtained from high vaginal and endocervical swabs

\begin{tabular}{|c|c|c|c|c|c|c|c|c|}
\hline \multirow{2}{*}{ Anaerobes } & \multicolumn{4}{|c|}{ High vaginal swab isolates } & \multicolumn{4}{|c|}{ Endocervical swab isolates } \\
\hline & $\begin{array}{c}\text { Women } \\
\text { prior to } \\
\text { IUCD } \\
\text { insertion } \\
(n=40)\end{array}$ & $\%$ & $\begin{array}{c}\text { Women } \\
\text { with IUCD } \\
\text { in situ } \\
(\mathbf{n}=\mathbf{8 0})\end{array}$ & $\%$ & $\begin{array}{l}\text { Women } \\
\text { prior to } \\
\text { IUCD } \\
\text { insertion } \\
(n=40)\end{array}$ & $\%$ & $\begin{array}{c}\text { Women } \\
\text { with IUCD } \\
\text { in situ } \\
(\mathbf{n}=\mathbf{8 0})\end{array}$ & $\%$ \\
\hline \multicolumn{9}{|l|}{ Gram positive: } \\
\hline Lactobacilli & 13 & 32.5 & 12 & 15 & 10 & 25 & 8 & 10 \\
\hline Peptostreptococci & 1 & 2.5 & 3 & 3.8 & 1 & 2.5 & 2 & 2.5 \\
\hline Actinomyces & 0 & 0 & 3 & 3.8 & 0 & 0 & 3 & 3.8 \\
\hline \multicolumn{9}{|l|}{ Gram negative: } \\
\hline Bacteroides & 3 & 7.5 & 6 & 7.5 & 3 & 7.5 & 7 & 8.8 \\
\hline Fusobacterium & 1 & 2.5 & 2 & 2.5 & 1 & 2.5 & 2 & 2.5 \\
\hline Prevotella & 1 & 2.5 & 2 & 2.5 & 1 & 2.5 & 2 & 2.5 \\
\hline
\end{tabular}

Lactobacilli were isolated at a lesser frequency from women with IUCD in situ when compared to women prior to insertion. (p<0.05). Actinomyces spp was isolated only from women with IUCD in situ and none from women prior to insertion. There was increase in other anaerobic bacterial organisms in women with IUCD in situ but not statistically significant.

Table.5 Distribution of Candida isolates

\begin{tabular}{|c|c|c|c|c|}
\hline & \multicolumn{2}{|c|}{ High vaginal swab isolates } & \multicolumn{2}{c|}{ Endocervical swab isolates } \\
\cline { 2 - 5 } & $\begin{array}{c}\text { Women prior to } \\
\text { IUCD insertion } \\
(\mathbf{n = 4 0})\end{array}$ & $\begin{array}{c}\text { Women with } \\
\text { IUCD } \text { in situ } \\
(\mathbf{n = 8 0})\end{array}$ & $\begin{array}{c}\text { Women prior to } \\
\text { IUCD insertion } \\
(\mathbf{n = 4 0 )}\end{array}$ & $\begin{array}{c}\text { Women with } \\
\text { IUCD in situ } \\
(\mathbf{n}=\mathbf{8 0})\end{array}$ \\
\hline Candida sp: & $3(7.5 \%)$ & $11(13.8 \%)$ & $2(5 \%)$ & $6(7.5 \%)$ \\
\hline C. albicans & 2 & 6 & 1 & 2 \\
\hline C. glabrata & 1 & 3 & 1 & 2 \\
\hline C. tropicalis & 0 & 1 & 0 & 0 \\
\hline C. dubliniensis & 0 & 1 & 0 & 2 \\
\hline
\end{tabular}

Increase in Candida isolates was seen in women with IUCD in situ when compared to women prior to insertion and the difference was not statistically significant ( $p>0.05)$. 
Table.6 Organisms isolated from removed IUCDs $(n=22)$ in relation to duration of device in situ

\begin{tabular}{|l|c|c|c|}
\hline \multicolumn{1}{|c|}{ IUCD isolates } & Below 1 year & 1 to 2 years & Above 2 years \\
\hline S. aureus & 1 & 2 & 2 \\
\hline $\begin{array}{l}\text { Coagulase negative } \\
\text { Staphylococci }\end{array}$ & 0 & 1 & 1 \\
\hline Enterococci hemolytic & 0 & 1 & 1 \\
\hline $\begin{array}{l}\text { Beta } \\
\text { streptococci }\end{array}$ & 1 & 1 & 0 \\
\hline Diphtheroids & 0 & 0 & 2 \\
\hline Escherichia coli & 2 & 1 & 1 \\
\hline Klebsiella & 0 & 0 & 1 \\
\hline Proteus & 0 & 1 & 1 \\
\hline $\begin{array}{l}\text { Gardnerella } \\
\text { vaginalis }\end{array}$ & 1 & 1 & 0 \\
\hline Lacto bacilli & 2 & 1 & 2 \\
\hline Peptostreptococci & 0 & 1 & 1 \\
\hline Actinomyces & 0 & 1 & 1 \\
\hline Bacteroides & 1 & 1 & 1 \\
\hline Fusobacterium & 0 & 0 & $\mathbf{1 8}$ \\
\hline Prevotella & 0 & 0 & 2 \\
\hline Candida sp & 2 & $\mathbf{1 4}$ & \\
\hline \multicolumn{1}{|c|}{ Total } & $\mathbf{1 0}$ & & \\
\hline
\end{tabular}

The isolation rate of Actinomyces and Candida from devices worn for more than 2 years was significantly increased $(\mathrm{p}<0.05)$ when compared to devices worn for 1 to 2 years.

Also the present study shows increase in anaerobic bacterial organisms in women with IUCD in situ but not statistically significant ( $>0.05)$. The studies $(11,12)$ have reported no major changes in the levels of aerobic and anaerobic bacteria in women with IUCD in situ.

In the present study, increase in Candida isolates was seen in women with IUCD in situ when compared to women prior to insertion and the difference was not statistically significant $(\mathrm{p}>0.05)$ (Table 5). This correlates with study by Elhag et al., (5) in which no significant occurrence of Candida was found in women with IUCD in situ. The isolation rate of Actinomyces from devices worn for more than 2 years was significantly increased $(\mathrm{p}<0.05)$ when compared to devices worn for 1 to 2 years (Table 6). This correlates with the study by Elhag et al., (5) and Mali et al., (6) in which prolonged use of copper IUCD promotes the growth of Actinomyces in the genital tract. The absence of Actinomyces from IUCDs worn for $<1$ year could be due to high copper concentration as stated by Duguid et al., (2a).

In conclusion, the present study shows that women prior to IUCD insertion with intermediate Nugents score turned out to bacterial vaginosis after insertion. Hence gynaecological examination prior to insertion will be useful to prevent infection. There was significant occurrence of Actinomyces and decreased isolation of lactobacilli in women with IUCD in situ. The isolation rate of 
Actinomyces and Candida was also increased with the duration of the device in utero.

The present study can be done in a large scale to find out the actual infection rate in IUCD users. Delay of treatment for Actinomyces infection favours evolution to pelvic abscesses and masses. Early diagnosis and early treatment may produce complete resolution. Hence the IUCD users require a regular gynaecological follow up, further investigation and treatment as needed to prevent complications.

\section{References}

1. Agarwal Krishna et al.,; Microbial and cytopathological study of intrauterine contraceptive device users; Indian journal of Medical Sciences, sep 2004, vol 58,No.9; pp.394-399

2. Catherine et al., Microbial flora of the vagina and cervix; J.clin.path, 1977, vol30, 745748

2a. Duguid et al., Studies on uterine tract infections and the IUCD with special reference to actinomycetes, British Journal of Obstetrics and Gynaecology suppl; 4:3240.

3. Ferraz do Lago R, Simoes JA, Bahamondes L, Camargo RP, Perrotti M, Monteiro I. Follow-up of users of intrauterine device with and without bacterial vaginosis and other cervicovaginal infections. Contraception. 2003 Aug; 68 (2):105-9.

4. Ferrer et al., Vaginal candidosis:epidemiological and etiological factors;Int J Gynecol Obstet 2000;71:S21S27

5. K.M.Elhag et al., The effect of a copper intrauterine contraceptive device on the microbial ecology of the female genital tract; J.Med.Microbiol, (1988); vol 25; 245251

6. Mali B et al., Actinomyces in cervical smears of women using intrauterine contraceptive devices, Acta cytol 1986; 30; 367-371

7. Nugent RP et al., Reliability of diagnosing bacterial vaginosis is improved by a standardised method of gram stain interpretation; J clin Microbiol 1991; 29:297-301.

8. Samar Ghazal et al.,; Effect of IUD on reproductive tract infection in the Northern west Bank; Middle East Journal of Family Medicine,2004; vol 5 (5)

9. Samar Ghazal et al.,; Epidimiology of Aerobic Bacterial Infections among IUD (Intrauterine Device) Users in the Northern West Bank; An-Najah Univ. J. Res. (N. Sc.), 2004; Vol. 18 (1)

10. Sayeste Demirezen et al., The association between copper containing IUCD and bacterial vaginosis;Cent Eur J Publ Health 2006;14 (3): 138-140

11. Tsanadis G, Kalantaridou SN, Kaponis A, Paraskevaidis E, Zikopoulos K, Gesouli, et al.,., Bacteriological cultures of removed intrauterine devices and pelvic inflammatory disease. Contraception. 2002 May; 65 (5): 339-42.

12. Ulstein et al., Microflora of cervical and vaginal secretion in women using copper and norgestrel releasing IUCDs;Acta Obstet Gynaecol Scand 1987,66 (4);321-322

13. Valicenti et al., Detection and prevalence of IUD associated Actinomyces colonization and related morbidity; JAMA; 1982; 247:1149-52

14. World Contraceptive Use 2005. New York: United Nations, Population Division.

15. Z.Pal et al., Biofilm formation on intrauterine devices in relation to duration of use; Journal of clinical microbiology;2005;54;1199-1203

\section{How to cite this article:}

Subha, K., R. Selvi, A.V.M. Balaji and Dheepa, D. 2017. Study of Microbial Flora of Female Genital Tract in Intrauterine Contraceptive Device Users. Int.J.Curr.Microbiol.App.Sci. 6 (6): 363-369. doi: https://doi.org/10.20546/ijcmas.2017.606.042 